\title{
Peningkatan Pengetahuan pada Ibu Hamil tentang Kelas Ibu sebagai Upaya Pencapaian Program Kelas Ibu Hamil
}

\author{
Intan Monik Pratami \\ Email: intanmonikpratami@gmail.com \\ Sekolah Tinggi Ilmu Kesehatan Brebes, Indonesia \\ J1. Raya Jatibarang KM.8 Janegara Brebes \\ Telp/Fax (0283 ) 6172290
}

\begin{abstract}
Abstrak
Kesehatan Ibu hamil sangat penting, kesehatan harus dilakukan semaksimal mungkin, jika ibunya kurang sehat maka anaknya juga ikut apa yang sedang hadapi ibunya. Banyak dampak buruk jika kesehatan ibu hamil kurang tepat, salah satunya bisa membuat kematian ibu hamil. Ini merupakan masalah yang banyak terjadi di masyarakat. Tujuan kelas ibu hamil adalah untuk meningkatkan pengetahuan, merubah sikap dan perilaku ibu agar memahami tentang kehamilan, perubahan tubuh dan keluhan selama kehamilan, perawatan kehamilan, persalinan, perawatan nifas, keluarga berencana pasca persalinan, penyakit menular dan akte kelahiran (Depkes 2011, h.2). Metode yang dilakukan untuk meningkatkan pengetahuan ibu hamil yaitu dengan pendidikan konseling. Penulis berharap setelah dilakukan pendidikan konseling ini maka ibu hamil dapat mengetahui pentingnya kelasi Ibu selama kehamilan. Hasil yang dapat diperoleh yaitu meningkatnya pengetahuan ibu hamil tentang pentingnya mengikuti kegiatan kelas Ibu di Desa Jatibarang Kidul, luaran yang diperoleh yaitu adanya media pendidikan kesehatan tentang Kelas Ibu di Desa Jatibarang Kidul.
\end{abstract}

Kata kunci: ibu hamil; kelas ibu hamil; bidan; pendidikan konseling.

\begin{abstract}
The health of pregnant women is very important, health must be done as much as possible, if the mother is not healthy, the child will also follow what the mother is facing. There are many bad effects if the health of pregnant women is not right, one of which can make the death of pregnant women. This is a common problem in society. The purpose of the class for pregnant women is to increase knowledge, change attitudes and behavior of mothers to understand pregnancy, body changes and complaints during pregnancy, pregnancy care, childbirth, postpartum care, postnatal family planning, infectious diseases and birth certificates (MOH 2011, p. 2). The method used to increase the knowledge of pregnant women is counseling education. The author hopes that after this counseling education is carried out, pregnant women can find out the importance of maternal chelation during pregnancy. The results that can be obtained are increasing knowledge of pregnant women about the importance of participating in Mother's class activities in Jatibarang Kidul Village, the output obtained is the existence of health education media about Mother's Class in Jatibarang Kidul Village.
\end{abstract}

Keywords:pregnant women; pregnancy classes; midwifes; counseling education 


\section{Pendahuluan}

Pengetahuan merupakan faktor yang sangat penting dalam membentuk tindakan seseorang sehingga kurangnya pengetahuan tentang kehamilan dapat mempengaruhi seseorang untuk mempunyai perhatian terhadap kesehatan ibu dan bayi. Kesehatan Ibu hamil sangat penting, kesehatan harus dilakukan semaksimal mungkin, jika ibunya kurang sehat maka anaknya juga ikut apa yang sedang hadapi ibunya. Banyak dampak buruk jika kesehatan ibu hamil kurang tepat, salah satunya bisa membuat kematian ibu hamil. Salah satu dari perbaikan pelayanan kebidanan adalah kelas ibu hamil yang merupakan sarana untuk belajar bersama tentang kesehatan bagi ibu hamil, dalam bentuk tatap muka dalam kelompok yang bertujuan untuk meningkatkan pengetahuan dan keterampilan ibuibu mengenai kehamilan, perawatan kehamilan, persalinan, perawatan nifas, perawatan bayi baru lahir, mitos, penyakit menular dan akte kelahiran (Notoatmojo, 2010).

Kelas Ibu Hamil merupakan kelompok belajar ibu-ibu hamil dengan umur kehamilan antara 4 minggu s/d 36 minggu (menjelang persalinan) dengan jumlah peserta maksimal 10 orang. Di kelas ini ibuibu hamil akan belajar bersama, diskusi dan tukar pengalaman tentang kesehatan Ibu dan anak (KIA) secara menyeluruh dan sistimatis serta dapat dilaksanakan secara terjadwal dan berkesinambungan. Kelas ibu hamil difasilitasi oleh bidan/tenaga kesehatan dengan menggunakan paket Kelas Ibu Hamil yaitu Buku KIA, Flip chart (lembar balik) (Depkes 2011, h.1).

Tujuan kelas ibu hamil adalah untuk meningkatkan pengetahuan, merubah sikap dan perilaku ibu agar memahami tentang kehamilan, perubahan tubuh dan keluhan selama kehamilan, perawatan kehamilan, persalinan, perawatan nifas, keluarga berencana pasca persalinan, penyakit menular dan akte kelahiran (Depkes 2011, h.2).

Pelaksana kelas ibu hamil adalah bidan. Bidan dalam hal ini mempunyai tugas sebagai fasilitator dalam program kelas ibu hamil, yang dalam pelaksanaan kelas ibu hamil fasilitator dapat meminta bantuan nara sumber untuk menyampaikan materi bidang tertentu (Depkes 2011, h.4). Penelitian yang dilakukan sulistyawati menyatakan bahwa tingkat pengetahuan $\mathrm{ibu}$ hamil tentang pemeriksaan kehamilan menurut hasil dari dari penelitian susilawati, baik $(71,9 \%)$ dan tidak baik (28,1\%), (Sulistyawati, 2012). Sedangkan tingkat pengetahuan ibu hamil tentang tanda bahaya kehamilan masih cukup (71,1\%), baik $(11,1 \%)$, dan kurang $(17,8 \%)$. (Marlina, 2012).

Hal ini menunjukkan bahwa masih kurangnya pengetahuan ibu hamil tentang tanda bahaya kehamilan, untuk meningkatkan pengetahuan tersebut maka diperlukan kegiatan kelas ibu hamil. Berdasarkan pernyataan diatas maka perlu nya memberikan pendidikan Pengetahuan Pada Ibu Hamil tentang kelas Ibu Sebagai Upaya Pencapaian Kelas Ibu.

\section{Metode}

Pelaksanaan pengabdian pada masyarakat dilakukan dengan metode ceramah dan diskusi menggunakan menggunakan media leafleat. Tahapan dalam kegiatan ini adalah (1 ) Persiapan dalam bentuk survey pada kelompok sasaran, (2) Koordinasi dan pengurusan ijin 
dengan instansi terkait (desa), (3) Persiapan media konseling dan sarana prasarana, tahapan selanjutnya yaitu (4) Pelaksanaan kegiatan pemberian pendidikan kesehatan tentang Pentingnya Kelas Ibu Hamil dengan metode (5) diskusi dan Tanya jawab dengan menggunakan media leaflet tahapan terakhir yaitu melakukan (6) follow up kegiatan tersebut.

\section{Hasil dan Pembahasan}

Kegiatan pengabdian ini telah dilaksanakan di Desa Jatibarang Kidul Kecamatan Jatibarang Kabupaten Brebes yang bertempat di Rumah Kader Ibu Nurati dibawah pengawasan Bidan Nuraeni pada hari selasa tanggal 24 Desember 2019 dengan jumlah peserta 13 orang. Peserta adalah Ibu Hamil, mereka sangat antusias mengikuti kegiatan pendidikan kesehatan tentang Pentingnya Kelas Ibu Hamil. Kegiatan ini dilakukan selama selama 60 menit.

Kegiatan pengabdian diawali dengan koordinasi dengan Bidan desa Jatibarang Kidul untuk mengundang Ibu Hamil pada saat pelaksanaan diawali dengan pendaftaran peserta yang hadir serta peserta diberikan pertanyaan seputar Ibu Hamil.

Sebelum dilakukan pendidikan kesehatan tentang Pentingnya Kelas Ibu Hamil diberikan beberapa pertanyaan. Pemberian pendidikan kesehatan tentang Kelas Ibu dilaksanakan dengan pemaparan dan metode diskusi dan tanya jawab dimana Ibu Hamil dan kader sangat antusias mendengarkan dan mengajukan pertanyaan.

\section{Kesimpulan}

Berdasarkan hasil pelaksanaan Pengabdian masyarakat yang telah dilakukan di Desa Jatibarang Kidul yang dihadiri sebanyak $13 \mathrm{Ibu}$ Hamil yang dan 3 orang kader terdapat peningkatan pengetahuan yang signifikan setelah diberikan pendidikan kesehatan dengan media leaflet. Dengan adanya pelaksanaan kegiatan Pendidikan Konseling Kesehatan pada Ibu hamil, ibu hamil dapat melakukan langkah pemantauan, pencegahan terjadinya kesakitan dan kematian pada ibu hamil.

\section{Daftar Pustaka}

[1] Departemen Kesehatan RI, Sistem Kesehatan Nasional. Jakarta: Depkes RI, 2011.

[2] S. Notoatmodjo, Promosi Kesehatan dan Perilaku Kesehatan. Jakarta: Rineka Cipta, 2010.

[3] Marlina, "Tingkat Pengetahuan Ibu Hamil tentang Tanda Bahaya Kehamilan,” 2012.

[4] Depkes RI, Pedoman Pelaksanaan Kelas Ibu Hamil. Jakarta: Departemen Kesehatan RI, 2011.

[5] Sulistyawati, "Tingkat Pengetahuan Ibu Hamil tentang Pemeriksaan Kehamilan," 2011. 